\title{
Ortaokul Öğrencilerinde Bilgisayar Oyun Bağımlılığı Düzeyinin Çeşitli Değişkenlere Göre İncelenmesi
}

Ata PESEN, Dr. Öğretim Üyesi, Siirt Üniversitesi, Eğitim Fakültesi, Eğitim Bilimleri Bölümü, SiirtTÜRKIYE, atapesen@siirt.edu.tr, Orcid: 0000-0003-1676-7444

Tuğçe ŞANLI, Yüksek Lisans Öğrencisi, Siirt Üniversitesi, Sosyal Bilimler Enstitüsü, Siirt-TÜRKİYE, tuat2326@outlook.com, Orcid: 0000-0002-2797-680X

Öz

$B u$ araştırmanın amacı ortaokul öğrencilerinin bilgisayar oyun bağımlılığı düzeyinin çeşitli değişkenlere göre incelenmesidir. Bu genel amaç doğrultusunda öğrencilerin cinsiyet, sinıf, evde bilgisayar olup olmama durumu ve akademik başarı ortalamaları değişkenlerine göre bilgisayar oyun bağımlılık düzeyleri incelenmiştir. Öğrencilerin bilgisayar oyun bağımlılığın ölçebilmek Horzum, Ayas ve Balta (2008) tarafından geliştirilen çocuklar için "Bilgisayar Oyun Bağımlılı̆̆ı Ölçeği" kullanılmıştır. Ölçek toplam 21 maddeden oluşan dört faktörlü bir yapıya sahiptir. Ölçeğin güvenilirliği için Horzum, Ayas ve Balta (2008) tarafından Cronbach alfa iç tutarlllık sayısı .85, bu araştırma için hesaplanan Cronbach alfa iç tutarlilik sayısı ise .84 olarak hesaplanmıştır. Bu araştırma 2016-2017 yıl güz eğitim ve öğretim döneminde gerçekleştirilmiştir. Araştırmanın örneklemi Siirt ili merkezinde yer alan farklı okulların 5.6.7. ve 8. sinıflarda okuyan öğrencilerden rastgele (tesadüfî) seçilmiştir. Elde edilen veriler SPSS 22.0 veri analiz programı kullanılarak çözümlenmiştir. Verilerin çözümlenmesinde Bağımsız örneklemler $t$ testi ve Tek yönlü varyans analizi (ANOVA) testi kullanılmıştır. Araştırma sonucunda erkek öğrencilerin bilgisayar oyun bağımllh̆̆ının kız öğrencilere göre anlamlı düzeyde farklllk tespit edilmiştir.

Anahtar Kelimeler: Bilgisayar, Oyun bağımlılı̆̆ı, Ortaokul, Öğrenci.

\section{Investigation of Computer Game Addiction Level of Secondary School Students According To Various Variables}

\footnotetext{
ABSTRACT The aim of this study is to investigate the level of computer addiction of secondary school students according to various variables. In line with this general goal, the computer game addiction levels were examined according to the variables of gender, class, whether or not having a computer at home and academic achievement average. Computer Game Addiction Scale for Children developed by Horzum, Ayas and Balta (2008) was used to measure computer game addiction. The scale has a four-factor structure consisting of a total of 21 items. For the reliability of the scale, Horzum, Ayas and Balta (2008) found the Cronbach alpha internal consistency as .85 , while in the present study it was calculated as .84. This research was conducted during the fall term 2016-2017 academic and the participants were randomly selected from the students at 5,6,7, and 8 grades in different schools in the city center of Siirt. The data obtaiend was analyzed via SPSS 22.0 data analysis program. Independent samples $t$ test and One-way analysis of variance (ANOVA) test were used to analyze the data. At the
} 
end of the research, it was determined that the computer game addiction of male students was significantly different than that of female students.

Keywords: Computer, Game addiction, Secodary School, Student.

\section{GİRIŞ}

Oyun çocuğun belli başlı kurallar dâhilinde vakit geçirirken hiçbir dış baskı etkisinde kalmadan kendi isteği ile giriştiği (Egemen, Yılmaz ve Akil, 2004), hiç kimsenin öğretemeyeceği konuları kendi kendine öğrendiği, sonucu düşünülmeden eğlenmek amacıyla yapılan tüm etkinliklerdir (Yavuzer, 2010). Oyun geçmişten günümüze kültürel birikimle birlikte çeşitlenen; özellikle okul öncesi ve ilköğretim çağındaki çocuklarda sosyal, kültürel, zihinsel, biyolojik ve fiziksel gelişimlerini destekleyen faaliyetlerdir. Çocuklar oyunda; mutluluk, sevinç, üzüntü, acı, kaygı, korku, nefret, kin, sevme, sevilme, bağımlılık ve bağımsızlık gibi birçok duyguyu öğrenirler (Akandere, 2003). Öğrendiği bu duyguları oyunlara yansitırlar. Oyunlar sayesinde çevresini araştırma, objeleri tanıma ve problem çözme yetenekleri kazanırlar. Gelişim açısından bakıldı̆̆ında oyun çocuğun doğal çevresinde kendi kendine öğrenmeler gerçekleştireceği en ideal ortamdır. Eskiden oynanan oyunlar günümüze göre yaşanılan kültürü, yapısını ve özelliklerini araştırmak için önemli bir değerken (Cengiz, 1997; Yavuzer, 2010) günümüzde oyunların medya ve toplumla birlikte değiştiğini ve yüz yüze iletişim kurulabilen sokak oyunlarının azaldığını belirtmiştir.

Teknolojideki gelişmeler birçok alanı etkilediği gibi çocukların oyun alışkanlıklarını da etkilemiştir. Geçmişte oyun parklarında ve sokaklarda arkadaşlarla birlikte gerçekleştirilen bu etkinlikler günümüzde evlerde ya da internet kafelerde video oyunları ve bilgisayar başında gerçekleştirilen sanal etkinlikler haline gelmiştir (Horzum, 2011). Teknolojik gelişmelerden önce oyunlar çocukların birlikte vakit geçirdikleri sosyal faaliyetlerken teknolojik gelişmelerle birlikte yerini çocukların bireysel olarak oynadıkları bilgisayar oyunlarına bırakmıştır.

Tüm dünyada ve ülkemizde bilgisayar ve internet kullanımının yaygınlaşması çocukların küçük yaşlarda bilgisayarlarla tanışması ile bilgisayar başında geçirilen zamanın artmasını beraberinde getirmiştir. TÜİK (2016) araştırmasında bilgisayar kullanma oranında her geçen y1l bir öncekine göre artış olduğu saptanmıştır.

Bilgisayar oyunlarının yaygınlaşması ve oyuna ayrılan sürenin artması çocuklar ve gençler üzerinde olumlu ve olumsuz bazı etkiler doğurmuştur. Oyunlar sosyal gelişim açısından önem taşımaktadır. İyi dizayn edilmiş ve çocuğun pedagojik gelişimine faydalı olan oyunlar sosyal gelişimi hızlandırırlar, çocukların eğlenmesini sağlar ve çocuğun fikir alışverişinde bulunarak bir konu üzerinde tartışma becerisi kazanmasını sağlar (Ward, 2004).

Bazı araştırmalara göre oyun ortamında çocukların öğrenme oranlarının normal bir ortama göre daha yüksek olduğu saptanmıştır. Oyun ortamında derslerin daha ilgi çekici ve öğrenci motivasyonunun daha yüksek olduğu belirlenmiştir. Oyun ile öğrenme öğrencinin 
öğrenebilme kapasitesine ilişkin özgüvenini arttırır ve etkinliği sürdürmesini sağlar. Böylece öğrencinin o dersteki öz yeterlik algısı dolayısıyla başarısı artar (Bayırtepe ve Tüzün, 2007).

Öğrencilerin dersleri eğitsel oyunlarla işlemeye olumlu baktıkları ve oyun tabanlı öğrenmeyi klasik yöntemlere (yazı yazmak, öğretmeni dinlemek) tercih ettikleri belirlenmiştir (Bakar, Tüzün ve Çağıltay, 2008). Ancak yapılan araştırmalara göre öğrencilerin en çok tercih ettikleri oyunlar aksiyon, spor, zekâ ve macera türündedir. Eğitsel oyunların en az tercih edilen oyunlar arasında yer alması bu oyunların dikkat çekici olmaması ve önem verilmediği için kaliteli eğitsel oyunların bulunmamasından kaynaklı olabilir (Çankaya ve Karamete, 2008).

Hiperaktif çocukların sabırsızlık ve acelecilik gibi belirgin özelliklerini törpülemek, zor durumlara yılmadan katlanma becerisi kazandırmak, sakinleştirici, kontrol edici, üstünlük duygusu kazandırıcı (Tarhan, 2007) gergin durumlara soğukkanlı yaklaşabilme özellikleri kazandırmak bilgisayar oyunlarının olumlu özellikleri arasında sayılabilir (Yalçın ve Bertiz, 2019). Ölçülü ve paylaşımcı bilgisayar oyunları çocuğun gelişimini yukarıda da belirttiğimiz gibi olumlu yönde etkileyebilir. Ancak uzun süre bilgisayar oyunu oynama çocuğun dengesini koruyamamasına, duygusal bozukluklara, obsesif ve agresif davranışlara, hiperaktiviteye, öğrenme bozukluklarına, kişilik değişimlerine, gerçek dünyadan uzaklaşmaya ve uzun süre hareketsiz kalmaya bağlı sağlık problemlerine, obeziteye, uyku bozukluğuna, kas ağrılarına ve iskelet bozukluklarına sebep olmaktadır. İnsanlar genel olarak bilgisayar başında geçirdikleri zamanı pek kavrayamaz (Sonay Kurt, İnce ve Arslan, 2014).

Bağımlılık, bir madde ya da davranışı kullanmayı bırakamama veya kontrol edememe şeklinde tanımlanabilir (Egger ve Rauterberg, 1996). Bağımlılık denince akla sadece sigara, alkol, uyuşturucu vb. madde bağımlılıkları gelmemeli, bunun yanında fiziksel bir maddeye dayanmayan, davranış tabanlı yeme bağımlılı̆̆ı, oyun bağımlılığı, bilgisayar bağımlılığı, televizyon bağımlılığı, alışveriş bağımlılığı, internet bağımlılığı vb. bağımlılıklardan da söz edilebilir (Greenfield, 1999; Kim ve Kim, 2002).

Yapılan araştırmalar bilgisayar oyunu oynama oranında ciddi artışların olduğunu ortaya koymuştur (Reiterer, 2010, Akt: Şahin ve Tuğrul, 2010). 1980'lerin ortasında çocuklar evde ya da atari salonlarında haftada 4 saat geçirirken günümüzde kızlar haftada 5,5 erkekler ise 13 saatini oyunlara ayırıyor (Christakis, Ebel, Rivara ve Zimmerman, 2004, Akt. Kocadağ ve Aksoy, ty). Türkiye İstatistik Kurumu verilerine göre Türkiye'de bilgisayar kullanma yaşı ortalama 8 olmuştur. Türkiye'de 6-15 yaş arası çocukların yüzde 60,5'i bilgisayar, yüzde 50,8 'i ise internet kullanmaktadır. Araştırmaya göre 06-15 yaş aralığındaki çocukların \%24,4'ünün kendi bilgisayarı var (TÜİK, 2013). Günümüzde çocukların en çok vakit harcadıkları eğlence araçlarından biri bilgisayar oyunlarıdır. Sadece eğlenme aracı olarak görülen bu oyunlar çocuklar üzerinde bağımlılık yaparak onlar üzerinde büyük bir tehlike arz edebilmektedir. İlköğretim okullarında okuyan öğrencilerin bilgisayar oyunlarına olan bağımlılık dereceleri çeşitli faktörlere göre değişim göstermektedir. Örneğin: erkek öğrencilerin kız öğrencilere, 4. Sınıf öğrencilerin 3.ve 5.sınıf öğrencilerine, maddi imkânları yüksek olan öğrencilerin, düşük olanlara nazaran oyun bağımlılığı yüksek bulunmuştur. Öztürk (2007) yaptığı çalışmada öğrencilerin \%23,4'ünün bilgisayar oyunlarının bağımlılık 
yaptığı görüşüne katıldıklarını bulmuştur. Sonay Kurt, İnce ve Arslan (2014) öğrencilerin bilgisayar oyunu oynama amaçları incelendiği araştırmasında öğrencilerin \%60,7'sinin eğlence, \%14,7'sinin boş zaman geçirme amaçlı oynadığı belirtirken; Kıran'ın (2011) yaptığ1 çalışmada öğrencilerin \%50'si boş zamanları değerlendirmek ve yorgunluk atmak amacıyla oynadıklarını belirtmişlerdir.

Gerçek dünyada yapılması imkânsız olan eylemleri oyunlarda kolaylıkla yapabilme ve oyunun eğlenceli ve rahatlatıcı yanı bilgisayar oyunlarının sık oynanması ile bu oyunların bağımlılık yapmasının en önemli nedenleri arasındadır. Bu durum oyun oynayan kişinin stresini oyunlarla attığını düşünmesi, oyunlardaki karakterlerin yerine kendini koyması ve hayalle yaşamayı gerçek hayata tercih etmesiyle bağımlılık haline gelir. Son zamanlarda dünya genelinde 100'ün üstünde, Türk asıllı 2 kullanıcının Blue Whale (Mavi Balina) oyunundaki talimatlar yüzünden intihar etmiş olma olasılığı üzerinde durulması (Yücel ve Şan, 2018) bilgisayar oyun bağımlılığı konusunun ciddiyetinin gündeme gelmesini sağlamıştır.

$\mathrm{Bu}$ araştırmanın amacı, ortaokul öğrencilerinin oyun bağımlılığı düzeylerinde cinsiyet, sınıf, bilgisayarın evde olup olmama durumu ve başarı ortalaması gibi değişkenlere göre anlamlı bir farklılık olup olmadığını tespit etmektir. Bu genel amaç doğrultusunda aşağıdaki araştırma sorularına cevap aranmıştır:

Cinsiyet değişkenine göre ortaokul öğrencilerinin oyun bağımlılık düzeyleri arasında istatistiksel olarak anlamlı bir farklılık var mıdır?

Sınıf değişkenine göre ortaokul öğrencilerinin oyun bağımlılık düzeyleri arasında istatistiksel olarak anlamlı bir farklılık var mıdır?

Evde bilgisayarın olup olmaması değişkenine göre ortaokul öğrencilerinin oyun bağımlılık düzeyleri arasında istatistiksel olarak anlamlı bir farklılık var mıdır?

Başarı ortalaması değişkenine göre ortaokul öğrencilerinin oyun bağımlılık düzeyleri arasında istatistiksel olarak anlamlı bir farklılık var mıdır?

\section{YÖNTEM}

\subsection{Araştırmanın Modeli}

$\mathrm{Bu}$ araştırma, betimsel bir araştırma olup genel tarama modelinde desenlenmiştir. Genel tarama modelleri, birden fazla elemandan oluşan bir evrende, evren hakkında genel bir yargiya varmak sebebiyle, evrenin tümü veya ondan alınacak bir grup, örnek ya da örneklem üzerinde yapılan tarama düzenlemeleridir (Karasar,1995).

\subsection{Evren ve Örneklem}

$\mathrm{Bu}$ araştırma ortaokul kademesinde okuyan öğrencilerin bilgisayar oyunu bağımlılığ düzeyini belirlemek amacıyla 2016-2017 yılı güz eğitim ve öğretim döneminde Siirt ili merkezinde yer alan farklı okulların 5., 6., 7. ve 8. sinıflarda okuyan öğrencilerden random 
yoluyla seçilmiştir. Tablo 1'de araştırmaya katılan öğrencilerin demografik özellikleri verilmiştir.

Tablo 1. Örneklem grubunun demografik özelliklerine ilişkin dağılımlar

\begin{tabular}{|c|c|c|c|}
\hline \multicolumn{2}{|c|}{ Değişkenler } & f & $\%$ \\
\hline \multirow{2}{*}{ Cinsiyet } & $\mathrm{K} 1 \mathrm{Z}$ & 101 & 38,4 \\
\hline & Erkek & 162 & 61,6 \\
\hline \multirow{4}{*}{ Sinif } & 5. sinif & 47 & 17,9 \\
\hline & 6. sinif & 101 & 38,4 \\
\hline & 7. sinif & 64 & 24,3 \\
\hline & 8. sinif & 51 & 19,4 \\
\hline \multirow{2}{*}{$\begin{array}{l}\text { Bilgisayarın evde olup } \\
\text { olmaması }\end{array}$} & Var & 175 & 66,5 \\
\hline & Yok & 88 & 33,5 \\
\hline \multirow{3}{*}{ Başarı ortalaması } & Orta & 70 & 26,6 \\
\hline & İyi & 101 & 38,0 \\
\hline & Pekiyi & 92 & 34,9 \\
\hline Toplam & & 263 & 100 \\
\hline
\end{tabular}

Tablo 1 incelendiğinde araştırmaya katılan toplam öğrenci sayısı 263'dir. Bu öğrencilerin 101'u kız 162'u erkek öğrencidir. Öğrencilerin 47'si 5. Sınıf, 101'i 6. Sınıf, 64'ü 7.sınıf ve 51'i 8. Sınıf öğrencilerinden oluşmaktadır. Öğrencilerin 175'inin evinde bilgisayar varken 88'inin evinde bilgisayar bulunmamaktadır. Öğrencilerin başarı düzeylerini belirlemede bir önceki dönemin karne notları temel alınmıştır. Öğrencilerin 70' i orta (55-69), 101'i iyi (70-84) ve 92'si pekiyi (85-100) başarı ortalamasına sahiptir.

\subsection{Veri Toplama Arac1}

$\mathrm{Bu}$ araştırmada veri toplama aracı olarak Horzum, Ayas ve Balta (2008) tarafından geliştirilen “Çocuklar İçin Bilgisayar Bağımlılığı Ölçeği”" kullanılmıştır. Ölçeğin güvenilirliği için Cronbach Alfa iç tutarlılık sayısı hesaplanmış ve iç tutarlılık .85 olarak bulunmuştur. Bu araştırma için hesaplanan Cronbach Alfa iç tutarlılık sayısı ise .84 olarak hesaplanmıştır. Ölçeğin tamamı olumlu maddelerden oluşmakta ve cevaplayıcılar ölçekten en az 21, en fazla 105 puan alabilmektedirler.

\subsection{Verilerin Analizi}

Araştırmanın sonucunda elde edilen veriler SPSS 22.0 veri analiz programı kullanılarak çözümlenmiştir. İstatistiksel analizlerde kullanılacak anlamlılık düzeyi $p \leq 0,05$ olarak alınmıştır. Araştırmada elde edilen veriler üzerinde yapılan analiz sonucunda verilerin Bağımsız örneklemler $t$ testi ve Tek yönlü varyans analizi (ANOVA) testi kullanılmıştır.

\section{BULGULAR}

Araştırmaya katılan öğrencilerin cinsiyet değişkenine göre bilgisayar oyun bağımlılığı düzeyleri arasında anlamlı bir farklılık olup olmadığını tespit etmek için Bağımsız örneklemler t testi yapılmış, veriler Tablo 2' de gösterilmiştir: 
Tablo 2. Ortaokul Öğrencilerinin bilgisayar oyun bağımlılığı düzeylerinin Cinsiyet Değişkenine Göre Analizi

\begin{tabular}{|c|c|c|c|c|c|c|c|}
\hline & & $\mathbf{N}$ & $\bar{x}$ & $\mathbf{S}$ & $\mathrm{sd}$ & $\mathbf{t}$ & $\underline{\mathbf{p}}$ \\
\hline Bilgisayar oyunи oynamaya engel olamama & $\mathrm{K} 1 \mathrm{z}$ & 101 & 18,2 & 5,7 & 261 & $-6,40$ &, $\mathbf{0 0 0}$ \\
\hline Bilgisayar oyunu ile gerçek hayat arasında bağ kurma & $\begin{array}{c}\text { LEkek } \\
\text { Krz } \\
\text { Erkek }\end{array}$ & $\begin{array}{l}102 \\
101 \\
162\end{array}$ & $\begin{array}{l}20,5 \\
8,7\end{array}$ & $\begin{array}{l}0, r \\
2,6 \\
3,7\end{array}$ & 261 & $-5,65$ &, $000^{* *}$ \\
\hline $\begin{array}{l}\text { Bilgisayar oyunu oynamaktan dolayı sorumlulukların } \\
\text { yerine getirememe }\end{array}$ & $\begin{array}{c}\text { Kız } \\
\text { Erkek }\end{array}$ & $\begin{array}{l}101 \\
162 \\
\end{array}$ & $\begin{array}{l}3,6 \\
4,3 \\
\end{array}$ & $\begin{array}{l}1,4 \\
1,8 \\
\end{array}$ & 261 & $-3,73$ &, $000^{* *}$ \\
\hline $\begin{array}{l}\text { Bilgisayar oyunu oynamayı başka etkinliklere tercih } \\
\text { etme }\end{array}$ & $\begin{array}{c}\text { Kiz } \\
\text { Erkek } \\
\end{array}$ & $\begin{array}{l}101 \\
162 \\
\end{array}$ & $\begin{array}{l}7,2 \\
9,0 \\
\end{array}$ & $\begin{array}{l}3,0 \\
3,6 \\
\end{array}$ & 261 & $-4,37$ &, $000^{* *}$ \\
\hline Ölçeğin Tümü & $\begin{array}{c}\text { Kiz } \\
\text { Erkek }\end{array}$ & $\begin{array}{l}101 \\
162 \\
\end{array}$ & $\begin{array}{l}35,7 \\
46,2 \\
\end{array}$ & $\begin{array}{c}8,9 \\
13,8 \\
\end{array}$ & 261 & $-7,49$ &, $000^{* *}$ \\
\hline
\end{tabular}

Tablo 2 incelendiğinde, cinsiyet değişkenine göre ölçeğin tamamında ve tüm alt faktörlerde anlamlı farklılık olduğu görülmektedir. Alt faktörler incelendiğinde bilgisayar oyunu oynamaya engel olamama ( $\mathrm{t}=-6.40)$, bilgisayar oyununu ile gerçek hayat arasında bağ kurma $(t=-5.65)$, bilgisayar oyunu oynamaktan dolayı sorumluluklarını yerine getirememe $(t=-3,73)$ ve bilgisayar oyunu oynamayı başka etkinliklere tercih etme $(t=-4,37)$ öğrencilerin cinsiyeti bakımından istatistiksel olarak anlamlı fark $(\mathrm{p} .<.05)$ olduğu tespit edilmiştir. Araştırmaya katılan erkek öğrencilerin $\left(x^{-}=46,2\right)$ kız öğrencilere göre $\left(x^{-}=35,7\right)$ bilgisayar oyun bağımlılık düzeylerinin anlamlı düzeyde farklılaştığı bulunmuştur ( $\mathrm{t}=-7,49, \mathrm{p}<.05)$.

Öğrencilerin sınıf değişkenine göre bilgisayar oyun bağımlılı̆̆ı düzeylerinde anlamlı bir fark olup olmadığını tespit etmek için Tek yönlü varyans analizi (ANOVA) testi yapılmış, sonuçlar Tablo 3'te gösterilmiştir:

Tablo 3. Ortaokul Öğrencilerinin bilgisayar oyun bağımlılığı düzeylerinin Sınıf Düzeylerine Göre Analizi

\begin{tabular}{|c|c|c|c|c|c|c|c|c|c|c|c|}
\hline Faktörler & Sinıf & $\mathbf{N}$ & $\bar{x}$ & SS & & $\begin{array}{c}\text { Kareler } \\
\text { Top. }\end{array}$ & sd & $\begin{array}{c}\text { Kareler } \\
\text { Orta. }\end{array}$ & $\mathbf{f}$ & p & Fark \\
\hline \multirow{5}{*}{$\begin{array}{l}\text { Bilgisayar oyunu } \\
\text { oynamaya engel } \\
\text { olamama }\end{array}$} & 5. sinif & 47 & 22,80 & 1,31 & Gruplar & & \multirow{5}{*}{3} & \multirow{2}{*}{190,86} & & \multirow{5}{*}{,036 } & \multirow{5}{*}{$6-8$} \\
\hline & 6. sinif & 101 & 23,05 &, 82 & aras1 & $5 / 2,58$ & & & & & \\
\hline & 7. sinif & 64 & 21,01 & ,93 & Grun ici & 1708806 & & 65.97 & 2,89 & & \\
\hline & 8.sinif & 51 & 19,24 & 1,07 & Urup IçI & $1 / 000,00$ & & 05,91 & & & \\
\hline & Toplam & 263 & 21,78 & 8,21 & Toplam & 17660,64 & & & & & \\
\hline \multirow{5}{*}{$\begin{array}{l}\text { Bilgisayar oyunu ile } \\
\text { gerçek hayat } \\
\text { arasında bağ kurma }\end{array}$} & 5. sinif & 47 & 9,02 & ,59 & Gruplar & 263,69 & \multirow{5}{*}{3} & \multirow{2}{*}{87,89} & & \multirow{5}{*}{,000 } & \multirow{5}{*}{$\begin{array}{l}5-8 \\
6-8 \\
7-8\end{array}$} \\
\hline & 6. sinif & 101 & 8,46 &, 32 & arasi & & & & & & \\
\hline & 7. sinif & 64 & 7,85 & ,44 & \multirow{2}{*}{ Grup içi } & 2928,66 & & 1130 & 7,77 & & \\
\hline & 8.sinif & 51 & 6,05 &, 34 & & & & 11,30 & & & \\
\hline & Toplam & 263 & 7,95 & 3,49 & Toplam & 3192,35 & & & & & \\
\hline \multirow{5}{*}{$\begin{array}{l}\text { Bilgisayar oyunu } \\
\text { oynamaktan dolayl } \\
\text { sorumluluklartnı } \\
\text { yerine getirememe }\end{array}$} & 5. sinif & 47 & 4,04 & ,22 & Gruplar & 2,62 & \multirow{5}{*}{3} & & \multirow{5}{*}{,28 } & \multirow{5}{*}{, 835} & \multirow{5}{*}{ Yok } \\
\hline & 6. sinif & 101 & 4,13 &, 15 & aras1 & & &, 81 & & & \\
\hline & 7. sinif & 64 & 4,14 & ,24 & Grunisi & 789,00 & & 304 & & & \\
\hline & 8.sinıf & 51 & 3,88 & ,26 & Grup 1ç1 & & & 3,04 & & & \\
\hline & Toplam & 263 & 4,07 & 1,73 & Toplam & 791,62 & & & & & \\
\hline \multirow{5}{*}{$\begin{array}{l}\text { Bilgisayar oyunu } \\
\text { oynamayı başka } \\
\text { etkinliklere tercih } \\
\text { etme }\end{array}$} & 5. sinif & 47 & 8,77 & ,54 & Gruplar & 154,54 & \multirow{5}{*}{3} & \multirow{2}{*}{51,51} & \multirow{5}{*}{4,20} & \multirow{5}{*}{, 006} & \multirow{5}{*}{$6-8$} \\
\hline & 6. sinif & 101 & 9,08 & ,34 & arası & & & & & & \\
\hline & 7. sinif & 64 & 8,07 & ,42 & Grun ici & 317366 & & 1225 & & & \\
\hline & 8.sinıf & 51 & 7,03 & ,48 & Grup 1ç1 & 3173,00 & & 12,25 & & & \\
\hline & Toplam & 263 & 8,38 & 3,56 & Toplam & 3328,21 & & & & & \\
\hline \multirow{5}{*}{ Ölçeğin Tümü } & 5. sinif & 47 & 44,61 & 1,97 & Gruplar & 2813,45 & \multirow{5}{*}{3} & \multirow{2}{*}{937,81} & \multirow{5}{*}{5,65} & \multirow{5}{*}{, 001} & \multirow{5}{*}{$\begin{array}{l}5-8 \\
6-8\end{array}$} \\
\hline & 6. sinif & 101 & 44,75 & 1,32 & arasi & & & & & & \\
\hline & 7. sinif & 64 & 41,09 & 1,59 & Grun ici & 42981,042 & & & & & \\
\hline & 8.sinıf & 51 & 36,25 & 1,62 & Grup 1çı & & & 165,95 & & & \\
\hline & Toplam & 263 & 42,19 & 13,22 & Toplam & 45794,494 & & & & & \\
\hline
\end{tabular}


Tablo 3 incelendiğinde, öğrencilerin bilgisayar oyunu oynamaya engel olamama $(F(3,263)=2,89)$, Bilgisayar oyunu ile gerçek hayat arasında bağ kurma $(F(3,263)=7,77)$, Bilgisayar oyunu oynamayı başka etkinliklere tercih etme $(F(3,263)=4,20)$ ve ölçeğin tamaminda $(F(3,263)=5,65)$ sinıf değişkenine göre anlamlı bir farklılık tespit edilmiştir. Farklılık tespit edilen faktörlerde farklılığın hangi sinıflar arasında olduğunu tespit etmek için çoklu karşılaştırma testlerinden Tukey çoklu karşılaştırma testi kullanılmıştır.

Araştırmaya katılan öğrencilerden bilgisayar oyunu oynamaya engel olamama faktöründe 6. ve 8. Sinıflara okuyan öğrencilerden 6. sınıf öğrencileri daha yüksek bir bağımlılı̆̆a sahip olduğu, bilgisayar oyunu ile gerçek hayat arasında bağ kurma faktöründe 5 ve 8,6 ve 8 ile 7 ve 8 arasında alt sinıfların daha yüksek bağımlılık düzeyine sahip oldukları lehine ve bilgisayar oyunu oynamayı başka etkinliklere tercih etme faktöründe 5 ve 8,6 ve 8 arasında yine alt sınıfların daha yüksek bir bağımlılık puanına sahip olduğu tespit edilmiştir.

Öğrencilerin evlerinde bilgisayar olup olmaması durumuna göre bilgisayar oyun bağımlılığı düzeylerinin arasında anlamlı bir farklılık olup olmadığını tespit etmek için Bağımsız örneklemler $\mathrm{t}$ testi yapılmış, veriler Tablo 4 'te gösterilmiştir:

Tablo 4. Ortaokul Öğrencilerinin bilgisayar oyun bağımlılığı düzeylerinin Evlerinde Bilgisayar Olup Olmaması Değişkenine Göre Analizi

\begin{tabular}{|c|c|c|c|c|c|c|c|}
\hline & & $\mathbf{N}$ & $\bar{x}$ & $\mathbf{S}$ & $\mathrm{sd}$ & $t$ & $\mathbf{p}$ \\
\hline \multirow{2}{*}{ Bilgisayar oyипи oynamaya engel olamama } & Var & 175 & 22,03 & 8,77 & \multirow{2}{*}{261} & \multirow{2}{*}{, 75} & \multirow{2}{*}{, 45} \\
\hline & Yok & 88 & 21,28 & 6,98 & & & \\
\hline \multirow{2}{*}{ Bilgisayar oyunu ile gerçek hayat arasında bağ kurma } & Var & 175 & 7,88 & 3,44 & \multirow[b]{2}{*}{261} & \multirow[b]{2}{*}{,- 42} & \multirow[b]{2}{*}{, 67} \\
\hline & Yok & 88 & 8,07 & 3,59 & & & \\
\hline \multirow{2}{*}{$\begin{array}{l}\text { Bilgisayar oyunu oynamaktan dolayl sorumluluklarını yerine } \\
\text { getirememe }\end{array}$} & Var & 175 & 4,04 & 1,70 & \multirow{2}{*}{261} & \multirow{2}{*}{,- 42} & \multirow[b]{2}{*}{, 67} \\
\hline & Yok & 88 & 4,13 & 1,80 & & & \\
\hline \multirow{2}{*}{ Bilgisayar oyunu oynamayı başka etkinliklere tercih etme } & Var & 175 & 8,30 & 3,64 & \multirow[b]{2}{*}{261} & \multirow[b]{2}{*}{,- 52} & \multirow{2}{*}{,60 } \\
\hline & Yok & 88 & 8,54 & 3,40 & & & \\
\hline \multirow{2}{*}{ Ölçeğin Tümü } & Var & 175 & 42,26 & 14,19 & \multirow{2}{*}{261} & \multirow{2}{*}{, 13} & \multirow{2}{*}{, 89} \\
\hline & Yok & 88 & 42,04 & 11,10 & & & \\
\hline
\end{tabular}

Tablo 4 incelendiğinde, elde edilen verilere göre öğrencilerin evlerinde bilgisayar olup olmaması durumlarına göre bilgisayar oyun bağımlılık düzeyleri arasında anlamlı bir fark gözlemlenememiştir ( $>00.05$ ). Buna göre öğrencilerin evlerinde bilgisayar olup olmamasının istatistiksel olarak anlamlı bir etkiye sahip olmadığı tespit edilmiştir.

Öğrencilerin akademik başarı not ortalamalarına göre bilgisayar oyun bağımlılığı düzeylerinde anlamlı bir fark olup olmadığını tespit etmek için Tek yönlü varyans analizi (ANOVA) testi yapılmış, sonuçlar Tablo 5'te gösterilmiştir: 
Tablo 5. Ortaokul Öğrencilerinin bilgisayar oyun bağımlılığı düzeylerinin akademik başarı not ortalamalarına Göre Analizi

\begin{tabular}{|c|c|c|c|c|c|c|c|c|c|c|c|}
\hline Faktörler & Sinıf & $\mathbf{N}$ & $\bar{x}$ & SS & & $\begin{array}{c}\text { Kareler } \\
\text { Top. }\end{array}$ & $s d$ & $\begin{array}{c}\text { Kareler } \\
\text { Orta. }\end{array}$ & f & $\mathbf{p}$ & Fark \\
\hline \multirow{4}{*}{$\begin{array}{l}\text { Bilgisayar oyunu } \\
\text { oynamaya engel } \\
\text { olamama }\end{array}$} & Orta & 70 & 21,40 &, 85 & $\begin{array}{l}\text { Gruplar } \\
\text { aras1 }\end{array}$ & 20,63 & 2 & 10,31 & \multirow{4}{*}{, 15} & \multirow{4}{*}{,859 } & \\
\hline & Iyi & 101 & 22,09 &, 80 & Grup ici & 17640,01 & 260 & 67,84 & & & \\
\hline & Pekiyi & 92 & 21,72 & ,95 & & & & & & & \\
\hline & Toplam & 263 & 21,78 & 8,21 & Toplam & 17660,64 & 262 & & & & \\
\hline \multirow{3}{*}{$\begin{array}{l}\text { Bilgisayar oyunu } \\
\text { ile gerçek hayat } \\
\text { arasinda bă̆ } \\
\text { kurma }\end{array}$} & Orta & 70 & 8,68 &, 37 & $\begin{array}{l}\text { Gruplar } \\
\text { aras1 }\end{array}$ & 51,74 & 2 & 25,87 & \multirow{3}{*}{2,14} & \multirow{3}{*}{,119 } & \\
\hline & Iyi & 101 & 7,65 &, 34 & Grup ici & 3140,60 & 260 & 12.07 & & & \\
\hline & Toplam & 263 & 7,95 & $\begin{array}{l}3,40 \\
3,49\end{array}$ & Toplam & 3192,35 & 262 & & & & \\
\hline \multirow{3}{*}{$\begin{array}{l}\text { Bilgisayar oyunu } \\
\text { oynamaktan dolayı } \\
\text { sorumluluklarin } \\
\text { yerine getirememe }\end{array}$} & Orta & 70 & 4,54 & ,28 & Gruplar & 25,16 & 2 & 12,58 & \multirow{3}{*}{4,26} & \multirow{3}{*}{,015 } & \multirow{3}{*}{$\begin{array}{l}\text { Orta- } \\
\text { Pekiyi }\end{array}$} \\
\hline & $\begin{array}{c}\text { Iyi } \\
\text { Pekiyi }\end{array}$ & $\begin{array}{c}101 \\
92\end{array}$ & $\begin{array}{l}4,03 \\
3,75\end{array}$ & $\begin{array}{l}13 \\
, 15\end{array}$ & Grup içi & 766,46 & 260 & 2,948 & & & \\
\hline & Toplam & 263 & 4,07 & 1,73 & Toplam & 791,62 & 262 & & & & \\
\hline \multirow{3}{*}{$\begin{array}{l}\text { Bilgisayar oyunu } \\
\text { oynamayı başka } \\
\text { etkinliklere tercih } \\
\text { etme }\end{array}$} & Orta & 70 & 8,62 & ,39 & $\begin{array}{l}\text { Gruplar } \\
\text { aras1 }\end{array}$ & 16,85 & 2 & 8,42 & \multirow{3}{*}{,66 } & \multirow{3}{*}{, 517} & \\
\hline & $\begin{array}{c}\text { Iyi } \\
\text { Pekivi }\end{array}$ & $\begin{array}{c}101 \\
92\end{array}$ & $\begin{array}{l}8,52 \\
8,04\end{array}$ & $\begin{array}{r}, 35 \\
39\end{array}$ & Grup içi & 3311,35 & 260 & 12,73 & & & \\
\hline & Toplam & 263 & 8,38 & 3,56 & Toplam & 3328,21 & 262 & & & & \\
\hline \multirow{3}{*}{ Ölçeğin Tümü } & Orta & 70 & 43,25 & 1,44 & $\begin{array}{l}\text { Gruplar } \\
\text { aras1 }\end{array}$ & 164,52 & 2 & 82,26 & \multirow{3}{*}{, 46} & \multirow{3}{*}{,626 } & \\
\hline & $\begin{array}{l}\text { Iyi } \\
\text { Pekivi }\end{array}$ & $\begin{array}{c}101 \\
9 ?\end{array}$ & $\begin{array}{l}42,31 \\
41,23\end{array}$ & $\begin{array}{l}1,23 \\
1,54\end{array}$ & Grup içi & 45629,97 & 260 & 175,50 & & & \\
\hline & Toplam & 263 & 42,19 & 13,22 & Toplam & 45794,49 & 262 & & & & \\
\hline
\end{tabular}

Tablo 5 incelendiğinde, öğrencilerin Bilgisayar oyunu oynamaktan dolay1 sorumluluklarını yerine getirememe $(F(2,262)=4,26)$ faktöründe akademik başarı değişkenine göre anlamlı bir farklılık tespit edilmiştir. Farklılık tespit edilen faktörde farklılığın hangi gruplar arasında olduğunu tespit etmek için çoklu karşılaştırma testlerinden Tukey çoklu karşılaştırma testi kullanılmıştır.

Araştırmaya katılan Bilgisayar oyunu oynamaktan dolayı sorumluluklarını yerine getirememe faktöründe orta ve pekiyi başarıya sahip öğrencilerden orta düzey başarıdaki öğrencilerin pekiyi düzeyindeki öğrencilere göre anlamlı düzeyde daha yüksek bir bağımlılığa sahip olduğu tespit edilmiştir.

\subsection{SONUÇ VE TARTIŞMA}

Ortaokul öğrencilerinin oyun bağımlılı̆̆ının cinsiyet, sınıf düzeyi, bilgisayarın evde olup olmaması durumu ve akademik başarı değişkenleri açısından incelendiği bu araştırma, sonucunda ortaokul öğrencilerinin bilgisayar oyun bağımlılıklarının cinsiyete bağlı olarak farklılık gösterdiği tespit edilmiştir. Erkek öğrencilerin kız öğrencilere oranla bağımlılık düzeylerinin daha yüksek olduğu saptanmıştır. Elde edilen bu sonuç başka çalışmaların sonuçları ile paralellik göstermektedir (Bülbül, Tunç ve Aydil, 2018; Eryılmaz ve Çukurluöz, 2018; Gökçearslan ve Durakoğlu, 2014; Demirtaş Madran ve Ferligül Çakılcı, 2014; Şahin ve Tuğrul, 2012; Horzum, 2011; Keser ve Esgi, 2012; Bayraktar, 2001). Başka çalışmalarda ise bu çalışmanın aksine cinsiyet değişkenine göre oyun bağımlılık düzeyleri arasında anlamlı bir farklılık tespit edilmemiştir (Taş, Eker ve Anlı, 2014; Colwell, Grady ve Rhaiti, 1995; Horzum, 2011). Öncel ve Tekin (2015) ortaokul öğrencileri üzerine yaptığı araştırmaya kız öğrencilerin erkek öğrencilere göre; oyunu daha fazla hayatla ilişkilendirdikleri, oyundan dolayı 
görevlerini daha fazla aksattıkları ve oyunu başka etkinliklere daha çok tercih ettikleri sonucuna ulaşılmıştır. Griffiths (1999) de bayanların erkelere göre internet bağımlılık düzeyinin daha yüksek olduğunu tespit etmiştir. Bu durum çalışmanın yapıldı̆̆ı zaman veya toplumsal farklılıkla ilgili olabilir.

Araştırmada ortaokul öğrencilerinin bilgisayar oyun bağımlılığı düzeyleri arasında sınıf değişkeni açısından anlamlı bir farklılık olduğu belirlenmiştir. Sınıf düzeyi arttıkça bilgisayar oyun bağımlılık düzeyinin azaldığı tespit edilmiştir. Alt sınıflarda okuyan öğrencilerin üst sınıf öğrencilere göre bilgisayar oyun bağımlılık düzeylerinin yüksek olması yaş faktörüne bağlı olarak aileler tarafında daha fazla tölere edildikleri şeklinde yorumlanabilir. Öncel ve Tekin (2015) ise sınıf düzeyi arttıkça oyun bağımlılık düzeyinin arttığını tespit etmiştir. Horzum (2011)'un oyun bağımlılığını incelediği araştırmasında 4. sinıf öğrencilerinin 3. ve 5. sinıf öğrencilerine göre oyun bağımlılık düzeylerinin daha yüksek olduğunu dolayısıyla oyun bağımlılığının sınıf düzeyleri açısından farklı olduğunu saptamıştır. Horzum araştırmasındaki bu durumun 4. sınıf öğrenci grubunda 3.ve 5. sınıf öğrencilerine göre bilgisayara sahip olma durumu ve bilgisayar dersiyle birlikte bilgisayarda geçirilen zamanın artması olasılıklarıyla nitelemiştir. Şahin ve Tuğrul (2012) ise 4. ve 5. sınıf öğrencilerinde "oyundan dolayı görevleri aksatma" ve "oyunu başka etkinliklere tercih" alt boyutları bakımından 5. sınıf lehine anlamlı farklılığın olduğunu tespit etmiştir. Eryılmaz ve Çukurluöz (2018) ise lise öğrencileri üzerine yapmış oldukları çalışmada sınıf değişkenine göre dijital bağımlılık düzeylerinde; Taş, Eker ve Anlı (2014) ise oyun bağımlılık düzeylerinde anlamlı bir farklılık olmadığını tespit etmiştir.

$\mathrm{Bu}$ araştırmada bilgisayar oyun bağımlılığı ile bilgisayarın evde olup olmaması durumu arasında anlamlı bir farklılık gözlemlenmemiştir. Benzer şekilde Öncel ve Tekin (2015) ortaokul öğrencilerinin Horzum (2011) da ilköğretim 3. 4. ve 5. sınıf öğrencilerinin evde bilgisayara sahip olma durumuna göre oyun bağımlılık düzeyleri arasında bir farklılık olmadığını saptamıştır. Sonay Kurt, İnce ve Arslan (2014) öğrencilerin bilgisayara karşı tutumlarını inceledikleri araştırmalarında bilgisayarın evde olup olmama durumunun öğrencilerin tutumunu değiştirmediğini saptamışlardır. Bu bulgu ile farklılık gösteren araştırma sonuçları da vardır. Şahin ve Tuğrul (2012) ilköğretim öğrencilerinde oyun bağımlılığı çalışmasında evde bilgisayara sahip olan öğrencilerin bilgisayar oyunu bağımlılık puanının bilgisayarı olmayan öğrencilerin bilgisayar oyunu bağımlılık puanından daha yüksek olduğu saptamıştır. Bu sonuç Onay, Tüfekçi ve Çağıltay'ın (2005) kişinin bilgisayar sahibi olup olmamasının bağımlılık üzerine etkisini araştırdıkları çalışmalarında bilgisayar sahibi olan öğrencilerin olmayanlara göre bilgisayar oyunu bağımlılı̆̆ının daha fazla olması sonucuyla aynı doğrultudadır (Horzum, 2011).

Bilge (2012) özel okulda okuyan 5. sınıf Öğrencilerinin oyun bağımlılı̆̆ını incelediği araştırmasında bağımlılık ile süre arasında anlamlı fark olduğunu, bilgisayarı bir saat kullananlarla üç saat kullananlar arasında farklılık olduğunu belirlemiştir. Oyun çocukların hayatında önemli bir yerdedir ve bu nedenle bilgisayar sahibi olmasa bile bulabildiği her yerde bilgisayar oyunu oynamaya çalıştıkları görülmektedir. Bu durum bilgisayarın evde olup olmamasının oyun bağımlılığını etkilememesinin sebepleri arasında olabilir. 
Yapılan bu araştırmada, başarı düzeyi arttıkça bağımlılık düzeyinin düştüğü tespit edilmiştir. Eryılmaz ve Çukurluöz (2018) lise öğrencilerinde de benzer bir sonuç elde etmiştir. Araştırmaya göre Bilgisayar oyunu oynamaya engel olamama, Bilgisayar oyunu ile gerçek hayat arasında bağ kurma, Bilgisayar oyunu oynamayı başka etkinliklere tercih etme faktörlerinde ve toplam bilgisayar oyun bağımlılığı düzeyinin akademik başarı not ortalamaları üzerinde anlamlı fark yaratmadığı görülmektedir. Yapılan araştırmada öğrencilerin bilgisayar bağımlılık düzeyinde akademik başarı değişkenine göre sadece "Bilgisayar oyunu oynamaktan dolayı sorumluluklarını yerine getirememe" alt boyutunda orta düzey başarılı öğrenciler lehine pekiyi düzeyinde başarılı öğrenciler arasında anlamlı bir fark olduğu sonucuna ulaşılmıştır. Eryılmaz ve Çukurluöz (2018) dijital bağımlılık ölçeği "sosyal hayata etki" boyutu için takdir alan öğrencilerin 1 zayıf, belge alamayan ve teşekkür belgesi alan öğrencilerden anlamlı derecede farklı olduğunu tespit etmiştir. Torun, Akçay ve Çoklar (2015) ise Bilgisayar Oyunlarının öğrencilerin akademik davranışları üzerinde etkisinin düşük olduğunu tespit etmiştir.

\section{5.ÖNERILER}

$\mathrm{Bu}$ araştırmada elde edilen sonuçlar doğrultusunda aşağıdaki öneriler sunulmuştur:

1. Araştırmada ortaokul öğrencilerin bilgisayar oyun bağımlığının cinsiyet değişkenine göre farklılaşmasının sebepleri nitel çalışmalar ile araştırılabilir.

2. Sınıf düzeyi yükseldikçe bilgisayar oyun bağımlılık düzeyi düşmüştür. Yaşı daha küçük olan öğrencilerin daha yüksek bir bağımlılık gösterme sebepleri üzerine araştırmalar yapılabilir. Liselerde durumun nasıl olduğu üzerine araştırma yapılabilir.

3. Bilgisayar oyun bağımlılığı evde bilgisayar olup olmama durumuna göre değişmemiştir. Öğrencilerin bilgisayar oyunlarını oynamak için hangi araçları tercih ettiği incelenebilir.

4. Akademik başarı bilgisayar oyun bağımlılık düzeyinde anlamlı bir etkiye sahip olmaması her öğrenciye hitap edecek türde oyunların var olduğu şeklinde yorumlanabilir. Buna göre farklı akademik başarılara sahip öğrencilerin ne tür oyunlar tercih ettikleri araştırılabilir.

5. Bu araştırma Siirt il merkezinde ortaokul öğrencileri ile sınırlıdır. Daha büyük örneklemle yeni çalışmalar yapılması yararlı olacaktır. 


\section{KAYNAKÇA}

Akandere, M. (2003) Eğitici Okul Oyunları. Ankara, Nobel Yayın Dagıtım.

Akçay, D., \& Öztepe, H. (2012). Okul Öncesi Eğitim Alan Çocukların ve Ailelerinin Bilgisayar Oyunu Oynama Alışkanlıklarının Değerlendirilmesi, Çocuk Dergisi 12(2),66-71.

Bakar, A., Tüzün, H., \& Çağıltay, K. (2008). Öğrencilerin eğitsel bilgisayar oyunu kullanımına ilişkin görüşleri: Sosyal bilgiler dersi örneği. Hacettepe Üniversitesi Eğitim Fakültesi Dergisi, 35(35).

Bayırtepe, E., \& Tüzün, H. (2007). Oyun-tabanlı öğrenme ortamlarının öğrencilerin bilgisayar dersindeki başarıları ve öz-yeterlik algıları üzerine etkileri. Hacettepe Üniversitesi Eğitim Fakültesi Dergisi, 33(33), 41-54.

Bayraktar, F. (2001). İnternet kullanımının ergen gelişimindeki rolü. Yüksek Lisans Tezi, Ege Üniversitesi Sosyal Bilimler Enstitüsü, İzmir.

Bilge, F. (2012). Bir Grup İlköğretim Öğrencisinde Bilgisayara Yönelik Bağımlılık Eğilimi Değerlendirmesi, Hacettepe Üniversitesi Eğitim Fakültesi Dergisi (H. U. Journal of Education), 96-105

Bülbül, H., \& Tunç, T. (2018). Telefon ve oyun bağımlılığı: Ölçek incelemesi, başlama yaşı ve başarıyla ilişkisi. Visionary E-Journal/Vizyoner Dergisi, 9(21).

Cengiz, S. A. (1997). Karadeniz Ereğli örneğinde çocuk oyunlarının halk bilim açısından değerlendirilmesi, B. Onur (Ed.), Çocuk Kültürü, I. Ulusal Çocuk Kültürü Kongresi Bildirileri (ss. 441-476). Ankara: Ankara Üniversitesi Çocuk Kültürü Araştırma ve Uygulama Merkezi Yayınları.

Colwell, J., Grady, C., \& Rhaiti, S. (2006). Computer games, self-esteem and gratification of needs in adolescents. Journal of Community \& Applied Social Psychology, 5(3), 195206.

Çankaya, S., \& Karamete, A. (2008). Eğitsel bilgisayar oyunlarının öğrencilerin matematik dersine ve eğitsel bilgisayar oyunlarına yönelik tutumlarına etkisi. Mersin Üniversitesi Eğitim Fakültesi Dergisi, 4(2).

Demirtaş Madran, H. A., \& Ferligül Çakılcı, E. (2014). Çok oyunculu çevrimiçi video oyunu oynayan bireylerde video oyunu bağımlılığı ve saldırganlık. Anatolian Journal of Psychiatry/Anadolu Psikiyatri Dergisi, 15(2).

Egemen, A., Yılmaz, Ö., \& Akil, İ. (2004). Oyun, Oyuncak ve Çocuk, ADÜ Tıp Fakültesi Dergisi, 39-42.

Egger, O., \& Rauterberg, M. (1996). Internet behavior and addiction. Semester thesis (Swiss Federal Institute of Technology, Zurich, 1996).

Eryılmaz, S., \& Çukurluöz, Ö. (2018). Lise öğrencilerinin dijital bağımlılıklarının incelenmesi: Ankara ili, Çankaya İlçesi ÖRNEĞİ. Elektronik Sosyal Bilimler Dergisi, 17(67), 889912.

Gökçearslan, Ş., \& Durakoğlu, A. (2014). Ortaokul öğrencilerinin bilgisayar oyunu bağımlılık düzeylerinin çeşitli değişkenlere göre incelenmesi, Dicle Üniversitesi Ziya Gökalp Eğitim Fakültesi Dergisi, 419-435.

Greenfield, D. N. (1999). Psychological characteristics of compulsive Internet use: A preliminary analysis. Cyberpsychology \& behavior, 2(5), 403-412. 
Griffiths, M. D. (1999). Internet addiction: fact or fiction?, The Psychologist, 12(5), (pp. 246 250).

Horzum, M. B., Ayas, T., \& Balta, Ö. Ç. (2008). Çocuklar İçin Bilgisayar Oyun Bağımlılığı Ölçeği. Türk PDR (Psikolojik Danışma ve Rehberlik) Dergisi, III(30), 76-88.

Horzum, M.B. (2011). İlköğretim öğrencilerinin bilgisayar oyunu bağımlılık düzeylerinin çeşitli değişkenlere göre incelenmesi. Eğitim ve Bilim, 36(159), 56-68.

Karasar, N. (1995). Bilimsel araştırma yöntemi (7. basim). Ankara: 3A Arastırma Eğitim Danışmanlık Ltd. fiti.

Keser, H., \& Esgi, N. (2012). An Analysis of Self-Perceptions of Elementary School Students in Terms of Computer Game Addiction. Procedia - Social and Behavioral Sciences, 46, $247-251$

Kıran Ö. (2011) Şiddet İçeren Bilgisayar Oyunlarının Ortaöğretim Gençliği Üzerindeki Etkileri (Samsun Örneği). Samsun Sempozyumu, Samsun.

Kim, S., \& Kim, R. (2002). A study of internet addiction: Status, causes, and remedies. Journal of Korean Home Economics Association English Edition, 3(1).

Kocadağ, T., \& Aksoy, M. E. (Tarih yok). Dil öğretiminde teknoloji kullanımı. 17 Kasım 2018 tarihinden

https://www.researchgate.net/profile/Tugba_Kocadag_Uenver/publication/322682355

_Dil_Ogretiminde_Teknoloji_Kullanimi/links/5b0415b80f7e9be94bdb2f0c/Dil-

Oegretiminde-Teknoloji-Kullanimi.pdf adresinden ulaşılmıştır.

Öncel, M., \& Tekin, A. (2015). Ortaokul öğrencilerinin bilgisayar oyun bağımlılığı ve yalnızlık durumlarının incelenmesi. İnönü Üniversitesi Eğitim Bilimleri Enstitüsü Dergisi, 2(4), 7-17.

Öztürk D. (2007) Bilgisayar Oyunlarının Çocukların Bilişsel ve Duygusal Gelişimleri Üzerindeki Etkilerinin İncelenmesi [Yüksek Lisans Tezi]. Dokuz Eylül Üniversitesi, İzmir.

Sonay Kurt, A., İnce, P., \& Arslan, F. T. (2014). İlköğretim ikinci kademede öğrenim gören öğrencilerin bilgisayara karşı tutumları. The Journal of Pediatric Research, 1(1), 22-27.

Şahin, C., \& Tuğrul, V. M. (2012). İlköğretim öğrencilerinin bilgisayar oyunu bağımlılık düzeylerinin incelenmesi. Zeitschrift für die Welt der Türken/Journal of World of Turks, 4(3), 115-130.

Tarhan, N. (2007). Çocuklar bilgisayar oyunlarından etkilenir mi. Tefekkür Dergisi, 19(1).

Taş, İ, Eker, H, \& Anlı, G. (2014). Orta Öğretim Öğrencilerinin İnternet Ve Oyun Bağımlılık Düzeylerinin İncelenmesi. Online Journal Of Technology Addiction \& Cyberbullying, 1 (2), 37-57. Retrieved from http://dergipark.gov.tr/ojtac/issue/28472/303451

Torun, F., Akçay, A., \& Çoklar, A., N. (2015). Bilgisayar oyunlarının ortaokul öğrencilerinin akademik davranış ve sosyal yaşam üzerine etkilerinin incelenmesi. Karaelmas Eğitim Bilimleri Dergisi, 3(1), 25-35.

TÜİK. (2013). 06-15 Yaş Grubu Çocuklarda Bilişim Teknolojileri Kullanımı ve Medya. 22 Ağustos 2018 tarihinde https://sosyalmedya.co/tuik-cocuklarin-internet-bilgisayartelefon-kullanimi/ adresinden erişildi. 
TÜİK. (2016). Hane Halkı Bilişim Teknolojileri Kullanım Araştırması, TÜİK. 16 Ağustos 2016 tarihinde http://www.tuik.gov.tr/PreHaberBultenleri.do?id=21779 adresinde yayımlanmıştır.

Ward, L. (2004). Computer games can help children learn. The Guardian Wednesday, October 27.

Yalçın, S., \& Bertiz, Y. (2019). Üniversite öğrencilerinde oyun bağımlılığının etkileri üzerine nitel bir çalışma. Bilim, Eğitim, Sanat ve Teknoloji Dergisi (BEST Dergi), 3(1), 27-34.

Yücel, G., \& Şan, Ş. (2018). Dijital Oyunlarda Bağımlılık ve Şiddet: Blue Whale Oyunu Üzerinde Bir İnceleme. AJIT-e: Online Academic Journal of Information Technology, 9(32). 